\title{
Response of manfalouty pomegranate trees to foliar application of humic acid and amino acids
} Khodair, O.A. ${ }^{1}$ and M.M.A. Abd El-Rahman ${ }^{2}$

${ }^{1}$ Horticulture Department, Faculty of Agriculture, Al-Azhar University, Assiut, Egypt.

${ }^{2}$ Horticulture Department (Pomology), Faculty of Agriculture, South Valley University, Qena, Egypt

\begin{abstract}
This study was carried out during 2018 and 2019 seasons for examining humic acid and amino acids effects on the yield and fruit quality of Manfalouty pomegranate trees grown under Assiut region circumstances. The experiment was set up in a complete randomized block design with three replicates, one tree per each. Manfalouty pomegranate trees were treating with humic acid or amino acids three times. Spraying humic acid at $(1,2$ and $3 \%)$ or amino acids at $(0.5,1$ and $1.5 \%)$ was very effective in stimulating all physical and chemical characteristics of the fruits relative to spray with water (control). Humic acid (3\%) spraying gave the highest yield followed by amino acids $(1.5 \%)$. On the other side, all treatments significantly decreased the fruit cracking percentage compared to control. The least fruit cracking was recorded due to amino acids at $(0.5 \%)$ spraying. All treatments significantly increased fruit weight and fruit dimensions as well as arils percentage and juice contents compared to control. Moreover, humic acid at (1,2 and $3 \%)$ or amino acids at $(0.5,1$ and $1.5 \%)$ significantly improved the fruit chemical constituents, compared to control. Spray via any concentration of humic acid or amino acids had no significant differences. It could be concluded that foliar application of either humic acid at $1 \%$ or amino acids at $0.5 \%$ three times during the fruit growth of manfalouty pomegranate, there application had necessary to get high yield and reduction fruit cracking percentage with best fruit quality.
\end{abstract}

Keywords: humic acid, amino acid, Manfalouty pomegranate trees, yield, fruit quality.

\section{Introduction}

Pomegranate (Punica granatum L.) is one of the oldest and most important edible fruits and it was mentioned in the Holy Quran. The pomegranate trees are grown widely worldwide in arid and semi-arid regions (Sarkhosh et al., 2006). Components pomegranate have a wide range of clinical

*Corresponding author: M.M.A. Abd El-Rahman E-mail: montoali@yahoo.com

Received: December 19, 2020;

Accepted: January 26, 2021;

Published: January 30, 2021. applications and therefore important in human medicine (Lansky and Newman 2007). The edible parts of the fruit Pomegranate which arils comprise juice and seeds are a rich source of sugars, ascorbic acid, amino acids, minerals, pectin, fibers, phytoestrogens, polyphenolic flavonoids (Aviram et al., 2000). Pomegranate fruit juice have been shown antioxidative properties its rich ascorbic acid (vitamin $\mathrm{C}$ ), vitamin E ( $\alpha$-tocopherol), and $\beta$-carotene (Shukla et al., 2008). In addition, 
pomegranate fruit juice has been shown to have higher antioxidant activity than green tea with thrice (Gil et al., 2000). Because of the importance of pomegranate production in Egypt, it is natural the pomegranate growers to be mindful of the factors which many positively influence the productivity such as natural fertilization i.e amino acids and humic acid application. Respectively, used of humic acids to amelioration soil fertility and improve growth of plant and therefore increased the yield (Canellas et al., 2015). Humic acid is organic material multiplex extracted from the decomposition of plant matter produce as a mixture of soluble substances. This organic material used to enhance nutritional uptake, regulation hormones levels, and improvement stress tolerance (Khattab et al., 2014, Lotfi et al., 2015, Moghadam 2015, kamal et al., 2017 and Ghanbarpour et al., 2018).

Amino acids are necessary for promoting cell growth, since they are considered as precursors and constituents of proteins. They contain acids and basic groups as well as act as buffers, which led to maintain favourable $\mathrm{pH}$ value within the plant cell (Davies, 1982). Amino acids can directly or indirectly effects on physiological activities in plant growth and development. Foliar spraying of amino acids has been reported to shown the growth, yield and biochemical quality of fruit trees (Fayek et al., 2011; Khan et al., 2012; Omima et al., 2014 and Arabloo et al., 2017). Amino acids applied has been for improving the growth, yield and fruit quality of pomegranate trees (Khattab et al., 2014; Wassel et a.,l 2015, Kamal et al., 2017 and Mohamed et al., 2020). Hence, the target of this study was studied the effective of humic acid and amino acids on fruit quality of Manfalouty pomegranate cultivar grown under Assiut region conditions.

\section{Materials and Methods}

This study was conducted during two consecutive seasons of 2018 and 2019 on 35 years old mature pomegranate trees (Punica granatum L.) Manfalouty cultivar. The trees were grown the Experimental Orchards, Faculty of Agriculture, Assiut University, Egypt. Trees under studied were grown in clay soil at $5 * 5$ meters. All trees received the standard agricultural practices that are used in the orchards including soil fertilization, irrigation and pest control. Uniform twenty one trees were selected randomly for this experiment which included seven treatments the treatment was repeated three times with one tree for each replicate. The experiment was arranged in a complete randomized block.

The spraying treatments were arranged as follows.

Control (sprayed with water).

Sprayed humic acid at (1\%)

Sprayed humic acid at (2\%)

Sprayed humic acid at $(3 \%)$

Sprayed amino acids at $(0.5 \%)$

Sprayed amino acids at $(1 \%)$

Sprayed amino acids at (1.5\%)

The previous spraying compounds were used three times, tow, six and twelve weeks after fruit set. Humic acid (85\% potassium humates) and amino acids as a compound contains all the amino acids. Humic acid and amino acids solution were prepared by dissolving the assigned amount in the required water. trioton $\mathrm{B}$ at $0.1 \%$ was added to spraying solution as a surfactant to reduce surface tension and to facilitate the absorption of sprayed solution and using a back held sprayers. 
During both seasons all fruits were harvested in the second week of October, the following traits were measured: yield/tree $(\mathrm{kg})$, fruit cracking $(\%)$, fruit weight $(\mathrm{g})$, fruit dimension, arils (\%) and juice (\%) as well as total soluble solids (TSS), total acidity, reducing sugars and vitamin $\mathrm{C}$ content (ascorbic acid/100 ml juice) according to (A.O.A.C. 2000). Total anthocyanin content of juice was determined according to (Rabino and Mancinelli, 1986). Hydrolysable tannin content of juice was estimated according to (Cam and Hisil, 2010). All the obtained data were tabulated and statistically analyzed according to the procedure of (Snedecor and Cochran, 1972). Comparison the differences between means were by Duncan's multiple range test at 5\% level of probability (Duncan, 1955).

\section{Results}

\section{1- Yield and fruit cracking}

Data existed in Table (1) showed the effect of humic acid and amino acids on yield/tree and fruit cracking percentage of Manfalouty pomegranate trees during 2018 and 2019 seasons. It is obvious from obtained the data that the results took similar trend during the two studied seasons.

In general view, data indicated that all treatments significantly increased the yield/ tree compared to spray water (control). The highest values of yield/tree were found on the trees that sprayed by humic acid $3 \%$ or amino acids at $1.5 \%$ (108.40 and $108.0 \mathrm{~kg}$ as an av. of the two studied seasons), respectively. No significant differences were found among all tested concentrations of both spraying substances. On other hand, the lowest values of yield were found on control trees $(94.07 \mathrm{~kg}$ as an av. of the two studied seasons).
The obtained yield/tree were (107.17, $105.51,108.40,105.88,105.11,108.00$ and $94.07 \mathrm{~kg} /$ tree as an av. of the two studied season) due to spraying with humic acid $1 \%$, humic acid $2 \%$, humic acid $3 \%$, amino acids $0.5 \%$, amino acids $1 \%$ and amino acids 1.5 and spraying water (control), respectively. Hence, the corresponding increment percentage of yield/tree over sprayed water ones were $(13.95,12.16,15.23,11.80,11.73$ and $14.80 \%$, respectively). On the other hand, all treatments significantly decreased the fruit cracking percentage relative to control. The lowest values were recorded on the trees that sprayed by $0.5 \%$ amino acids (6.3\%), whereas, the highest ones were obtained on control (13.5\%) as an av. of the two studied seasons. No significant differences between all used treatments were recorded. The recorded fruit cracking percentage was $(8.9,8.3,8.6,6.3,6.8,6.6$ and $13.5 \%$ as an av. of the two studied season) due to spraying with $1 \%$ humic acid, $2 \%$ humic acid, 3\% humic acid, 0.5 amino acids, $1 \%$ amino acids and $1.5 \%$ amino acids and water spraying (control), respectively. Hence, the corresponding decrement percentage of fruit cracking percentage under control was attained (34.07, 38.51, 36.29, 53.33, 49.62 and $51.11 \%)$, respectively.

\section{2- Fruit properties}

\section{A- Physical fruit properties}

These Physical fruit properties include fruit weight, fruit dimension, pulp percentage and juice percentage. Data in Tables ( $1 \& 2)$ demonstrated that the fruit weight and its dimension took similar trend in response to different treatments. There results indicated that all treatments significantly increased all the studied physical fruit properties 
Khodair and Abd El-Rahman, SVU-International Journal of Agricultural Sciences, 3 (1): 10-17, 2021

comparative to control. Humic acid at $1 \%$ and amino acids at $0.5 \%$ gave the highest values of these traits, where the fruit weight reached $(446.9 \& 437.4 \mathrm{~g})$, arils \% (64.24 \& $63.58 \%)$ and juice percentage $(48.95 \&$
$47.20 \%$ as an av. of the two studied seasons), respectively.

Moreover, there were insignificant differences in these traits du to increase the humic acid or amino acids concentration.

Table (1) Influence of humic acid and amino acids spraying on yield/tree, fruit cracking, fruit weight (g) and arils (\%) of Manfalouty pomegranate during 2018 and 2019 seasons.

\begin{tabular}{lcccccccccccc}
\hline \multirow{2}{*}{ Treatment } & \multicolumn{3}{c}{ yield kg/tree } & \multicolumn{3}{c}{ Fruit cracking $(\%)$} & \multicolumn{3}{c}{ Fruit weight $(\mathrm{g})$} & \multicolumn{3}{c}{ Arils $(\%)$} \\
\cline { 2 - 13 } & 2018 & 2019 & Mean & 2018 & 2019 & Mean & 2018 & 2019 & Mean & 2018 & 2019 & Mean \\
\hline Control & $86.29^{\mathrm{c}}$ & $101.86^{\mathrm{b}}$ & 94.07 & $12.3^{\mathrm{a}}$ & $13.8^{\mathrm{a}}$ & 13.5 & $378.5^{\mathrm{b}}$ & $391.8^{\mathrm{b}}$ & 385.2 & $58.82^{\mathrm{b}}$ & $56.52^{\mathrm{b}}$ & 57.67 \\
\hline Humic acid 1\% & $98.50^{\mathrm{ab}}$ & $115.84^{\mathrm{a}}$ & 107.2 & $8.6^{\mathrm{b}}$ & $9.3^{\mathrm{b}}$ & 8.9 & $437.8^{\mathrm{a}}$ & $456.1^{\mathrm{a}}$ & 446.9 & $64.95^{\mathrm{a}}$ & $63.54^{\mathrm{a}}$ & 64.24 \\
\hline Humic acid 2\% & $95.86^{\mathrm{b}}$ & $115.17^{\mathrm{a}}$ & 105.5 & $7.4^{\mathrm{c}}$ & $9.2^{\mathrm{b}}$ & 8.3 & $429.9^{\mathrm{a}}$ & $433.0^{\mathrm{a}}$ & 431.5 & $64.66^{\mathrm{a}}$ & $63.24^{\mathrm{a}}$ & 63.95 \\
\hline Humic acid 3\% & $101.35^{\mathrm{a}}$ & $115.46^{\mathrm{a}}$ & 108.4 & $8.3^{\mathrm{b}}$ & $8.9^{\mathrm{b}}$ & 8.6 & $435.0^{\mathrm{a}}$ & $440.7^{\mathrm{a}}$ & 437.8 & $64.40^{\mathrm{a}}$ & $62.95^{\mathrm{a}}$ & 63.67 \\
\hline Amino acids 0.5\% & $98.46^{\mathrm{ab}}$ & $113.31^{\mathrm{a}}$ & 105.9 & $6.8^{\mathrm{c}}$ & $5.9^{\mathrm{d}}$ & 6.3 & $435.7^{\mathrm{a}}$ & $439.2^{\mathrm{a}}$ & 437.4 & $64.80^{\mathrm{a}}$ & $62.37^{\mathrm{a}}$ & 63.58 \\
\hline Amino acids 1\% & $99.27^{\mathrm{ab}}$ & $110.95^{\mathrm{a}}$ & 105.1 & $7.2^{\mathrm{c}}$ & $6.5^{\mathrm{c}}$ & 6.8 & $443.2^{\mathrm{a}}$ & $425.1^{\mathrm{a}}$ & 434.2 & $64.10^{\mathrm{a}}$ & $62.20^{\mathrm{a}}$ & 63.15 \\
\hline Amino acids 1.5\% & $102.70^{\mathrm{a}}$ & $113.30^{\mathrm{a}}$ & 108.0 & $6.4^{\mathrm{c}}$ & $6.8^{\mathrm{c}}$ & 6.6 & $438.9^{\mathrm{a}}$ & $429.2^{\mathrm{a}}$ & 434.1 & $63.80^{\mathrm{a}}$ & $61.95^{\mathrm{a}}$ & 62.87 \\
\hline
\end{tabular}

Not significantly differences between of the number followed by the same letters in the same column at $0.5 \%$ level of probability

Table (2) Influence of humic acid and amino acids spraying on fruit dimension $(\mathrm{cm})$ and juice $\%$ of Manfalouty pomegranate fruits during 2018 and 2019 seasons.

\begin{tabular}{lccccccccc}
\hline \multirow{2}{*}{ Treatment } & \multicolumn{3}{c}{ Fruit length $(\mathrm{cm})$} & \multicolumn{3}{c}{ Fruit dimension $(\mathrm{cm})$} & \multicolumn{3}{c}{ Juice $(\%)$} \\
\cline { 2 - 9 } & 2018 & 2019 & Mean & 2018 & 2019 & Mean & 2018 & 2019 & Mean \\
\hline Control & $7.89^{\mathrm{c}}$ & $7.60^{\mathrm{c}}$ & 7.74 & $8.38^{\mathrm{c}}$ & $7.95^{\mathrm{c}}$ & 8.16 & $43.14^{\mathrm{b}}$ & $40.55^{\mathrm{c}}$ & 41.84 \\
Humic acid 1\% & $9.86^{\mathrm{a}}$ & $9.50^{\mathrm{a}}$ & 9.68 & $10.47^{\mathrm{a}}$ & $9.93^{\mathrm{a}}$ & 10.00 & $48.42^{\mathrm{a}}$ & $49.49^{\mathrm{a}}$ & 48.95 \\
Humic acid 2\% & $9.46^{\mathrm{a}}$ & $9.12^{\mathrm{a}}$ & 9.29 & $10.05^{\mathrm{b}}$ & $9.54^{\mathrm{a}}$ & 10.02 & $49.36^{\mathrm{a}}$ & $48.86^{\mathrm{a}}$ & 49.11 \\
Humic acid 3\% & $9.31^{\mathrm{a}}$ & $8.96^{\mathrm{b}}$ & 9.13 & $9.88^{\mathrm{b}}$ & $9.38^{\mathrm{b}}$ & 9.63 & $48.54^{\mathrm{a}}$ & $49.02^{\mathrm{a}}$ & 48.78 \\
Amino acids 0.5\% & $9.70^{\mathrm{a}}$ & $9.34^{\mathrm{a}}$ & 9.52 & $10.30^{\mathrm{a}}$ & $9.77^{\mathrm{a}}$ & 10.03 & $47.60^{\mathrm{a}}$ & $46.81^{\mathrm{b}}$ & 47.20 \\
Amino acids 1\% & $9.23^{\mathrm{b}}$ & $8.89^{\mathrm{b}}$ & 9.02 & $9.80^{\mathrm{b}}$ & $9.30^{\mathrm{b}}$ & 9.55 & $48.13^{\mathrm{a}}$ & $47.61^{\mathrm{b}}$ & 47.87 \\
Amino acids 1.5\% & $9.15^{\mathrm{b}}$ & $8.81^{\mathrm{b}}$ & 8.98 & $9.72^{\mathrm{b}}$ & $9.22^{\mathrm{b}}$ & 9.47 & $47.72^{\mathrm{a}}$ & $48.12^{\mathrm{a}}$ & 47.92 \\
\hline
\end{tabular}

Not significantly differences between of the number followed by the same letters in the same column at $0.5 \%$ level of probability

The recorded fruit weight were (446.9, $431.5,437.8,437.4,434.2,434.1$ and 385.2 $\mathrm{g}$ as an av. of the two studied seasons) due to spray by humic acid at 1,2 or $3 \%$ either amino acids at $0 ., 1.0$ or $1.5 \%$ and spray water (control), respectively. Hence, corresponding the increment percentage of fruit weight over unsprayed ones were
$(16.01,12.01,13.65,13.55,12.72$, and $12.69 \%)$, respectively.

\section{$B$-Chemical fruit constituents}

Data represented in Tables ( $3 \& 4$ ) indicated that all spraying treatments, significantly improved the fruit chemical constituents in terms of increasing the total soluble solids, reducing sugars, anthocyanin and vitamin $\mathrm{C}$ contents and reducing, the tannins contents 
and total acidity percentage compared to water sprayed trees .

The high values of TSS (16.88\%), reducing sugar $(12.34 \%)$, and anthocyanin content $(66.90 \mathrm{mg} / 100 \mathrm{~g})$ and V.C. contents (28.28 $\mathrm{mg} / 100 \mathrm{ml}$ as an av. of the two studied seasons) were recorded due to spray by $2 \%$ humic acid, $1.5 \%$ amino acids, $1.5 \%$ amino acids and $0.5 \%$ amino acids, respectively.
These values were $(15.35,11.08,56.36$ and 23.50) on water sprayed trees (control), respectively. Hence, the corresponding increment percentage of these traits attained (9.97, 11.37, 18.70 and $20.34 \%$ ) due to spray $2 \%$ humic acid, $1.5 \%$ amino acids, $1.5 \%$ amino acids and $0.5 \%$ amino acids over sprayed water trees (control), respectively.

Table (3) Influence of humic acid and amino acids spraying on TSS (\%), reducing sugars (\%) and Anthocyanin (mg/100 g) of Manfalouty pomegranate juice during 2018 and 2019 seasons.

\begin{tabular}{lccccccccc}
\hline \multirow{2}{*}{ Treatment } & \multicolumn{3}{c}{ TSS (\%) } & \multicolumn{4}{c}{ Reducing sugars (\%) } & \multicolumn{3}{c}{ Anthocyanin $(\mathrm{mg} / 100 \mathrm{~g})$} \\
\cline { 2 - 9 } & 2018 & 2019 & Mean & 2018 & 2019 & Mean & 2018 & 2019 & Mean \\
\hline Control & $15.80^{\mathrm{b}}$ & $14.90^{\mathrm{b}}$ & 15.35 & $11.15^{\mathrm{b}}$ & $11.02^{\mathrm{b}}$ & 11.08 & $55.62^{\mathrm{b}}$ & $57.11^{\mathrm{b}}$ & 56.36 \\
Humic acid 1\% & $16.80^{\mathrm{a}}$ & $16.10^{\mathrm{a}}$ & 16.45 & $12.16^{\mathrm{a}}$ & $12.23^{\mathrm{a}}$ & 12.19 & $63.25^{\mathrm{a}}$ & $68.50^{\mathrm{a}}$ & 65.88 \\
Humic acid 2\% & $16.90^{\mathrm{a}}$ & $16.85^{\mathrm{a}}$ & 16.88 & $12.32^{\mathrm{a}}$ & $12.13^{\mathrm{a}}$ & 12.23 & $64.31^{\mathrm{a}}$ & $67.34^{\mathrm{a}}$ & 65.83 \\
Humic acid 3\% & $16.80^{\mathrm{a}}$ & $16.70^{\mathrm{a}}$ & 16.75 & $12.28^{\mathrm{a}}$ & $12.25^{\mathrm{a}}$ & 12.27 & $62.84^{\mathrm{a}}$ & $66.22^{\mathrm{a}}$ & 64.53 \\
Amino acids 0.5\% & $16.60^{\mathrm{a}}$ & $16.30^{\mathrm{a}}$ & 16.45 & $12.13^{\mathrm{a}}$ & $11.92^{\mathrm{a}}$ & 12.03 & $63.15^{\mathrm{a}}$ & $67.90^{\mathrm{a}}$ & 65.53 \\
Amino acids 1\% & $16.50^{\mathrm{a}}$ & $16.60^{\mathrm{a}}$ & 16.55 & $12.20^{\mathrm{a}}$ & $12.33^{\mathrm{a}}$ & 12.27 & $64.90^{\mathrm{a}}$ & $68.11^{\mathrm{a}}$ & 66.51 \\
Amino acids 1.5\% & $16.70^{\mathrm{a}}$ & $16.45^{\mathrm{a}}$ & 16.58 & $12.19^{\mathrm{a}}$ & $12.48^{\mathrm{a}}$ & 12.34 & $66.45^{\mathrm{a}}$ & $67.33^{\mathrm{a}}$ & 66.90 \\
\hline
\end{tabular}

Not significantly differences between of the number followed by the same letters in the same column at $0.5 \%$ level of probability

Table (4) Influence of humic acid and amino acids spraying on V.C, Acidity (\%) and tannins content (mg/100 ml of juice) of Manfalouty pomegranate juice during 2018 and 2019 seasons.

\begin{tabular}{lccccccccc}
\hline \multirow{2}{*}{ Treatment } & \multicolumn{3}{c}{ V.C $(\mathrm{mg} / 100 \mathrm{ml})$} & \multicolumn{3}{c}{ Acidity $(\%)$} & \multicolumn{3}{c}{ Tannins content $(\mathrm{mg} / 100 \mathrm{ml})$} \\
\cline { 2 - 10 } & 2018 & 2019 & Mean & 2018 & 2019 & Mean & 2018 & 2019 & Mean \\
\hline Control & $22.91^{\mathrm{b}}$ & $24.10^{\mathrm{b}}$ & 23.50 & $1.52^{\mathrm{a}}$ & $1.32^{\mathrm{a}}$ & 1.42 & $2.95^{\mathrm{a}}$ & $2.68^{\mathrm{a}}$ & 2.81 \\
Humic acid 1\% & $27.41^{\mathrm{a}}$ & $27.71^{\mathrm{a}}$ & 27.56 & $1.18^{\mathrm{b}}$ & $1.06^{\mathrm{b}}$ & 1.12 & $2.46^{\mathrm{b}}$ & $2.11^{\mathrm{b}}$ & 2.29 \\
Humic acid 2\% & $27.17^{\mathrm{a}}$ & $27.47^{\mathrm{a}}$ & 27.32 & $1.13^{\mathrm{b}}$ & $1.01^{\mathrm{b}}$ & 1.07 & $2.35^{\mathrm{b}}$ & $2.18^{\mathrm{b}}$ & 2.26 \\
Humic acid 3\% & $26.93^{\mathrm{a}}$ & $27.23^{\mathrm{a}}$ & 27.08 & $1.02^{\mathrm{b}}$ & $0.96^{\mathrm{b}}$ & 0.99 & $2.50^{\mathrm{b}}$ & $2.25^{\mathrm{b}}$ & 2.38 \\
Amino acids 0.5\% & $28.13^{\mathrm{a}}$ & $28.43^{\mathrm{a}}$ & 28.28 & $1.09^{\mathrm{b}}$ & $1.02^{\mathrm{b}}$ & 1.05 & $2.33^{\mathrm{b}}$ & $2.18^{\mathrm{b}}$ & 2.26 \\
Amino acids 1\% & $27.89^{\mathrm{a}}$ & $28.17^{\mathrm{a}}$ & 28.03 & $1.12^{\mathrm{b}}$ & $1.00^{\mathrm{b}}$ & 1.06 & $2.25^{\mathrm{c}}$ & $2.10^{\mathrm{b}}$ & 2.18 \\
Amino acids 1.5\% & $27.65^{\mathrm{a}}$ & $27.95^{\mathrm{a}}$ & 27.80 & $1.06^{\mathrm{b}}$ & $0.93^{\mathrm{b}}$ & 0.99 & $2.40^{\mathrm{b}}$ & $2.16^{\mathrm{b}}$ & 2.28 \\
\hline
\end{tabular}

Not significantly differences between of the number followed by the same letters in the same column at $0.5 \%$ level of probability

Contrastly, the lowest values of acidity were (0.99) and tannin content $(2.18 \mathrm{mg} / 100$ $\mathrm{ml} \mathrm{g}$ juice) as an av. of the two studied seasons) were observed on trees that sprayed with humic acid at $3 \%$ and amino acids $1.0 \%$ respectively. On other hand, the heights values of acidity (1.42\%) and tannins content $(2.81 \mathrm{mg} / 100 \mathrm{ml})$ as an av. of the two studied seasons were recorded on untreated ones (control). Hence, the corresponding decrement percentage of these traits attained $(30.28 \%)$ and $(22.45$ $\%)$, respectively. Moreover, the data indicated that there were no significant differences among spraying treatments on 
fruits studied traits in these study compared to some of them.

\section{Discussion}

Humic acid is a byproduct of plant disintegration, has numerous bio-stimulatory Characteristics that work to reduction abiotic stress (Canellas et al., 2015 and Moghadam 2015). Also, Humic acid It has a very important role in primary and secondary metabolism processes to modulate growth and increment water-use efficiency (Canellas et al., 2015). Humic acid is a multiplex mixture of aromatic organic acids, with diverse functional groups bearing sulphur, $\mathrm{N}, \mathrm{P}, \mathrm{C}, \mathrm{H}$ and $\mathrm{O}$, in varying percentage and metal ions and improve the availability of nutrients to plants (Thang et a.,l 2003). It encourages the conversion elements like $\mathrm{N}, \mathrm{P}, \mathrm{Fe}, \mathrm{Cu}$, and $\mathrm{Mg}$ in to available forms to plants (Adam 1999). Humic acid produce dormant effects in plant by stimulating enzyme activity, membrane permeability photosynthesis, increasing protein and vitamin content and yield of dry matter, ( Liu et al., 1998; Muscolo et al., 2007; El-Mohamady and Ahmed 2009; Mehran et al., 2013 and haggag et al., 2013). These finding were in agree with those found by (Ferrara and Brunetti 2010; Abd El-Razek et al., 2012; Hagagg et al., 2013; Mehran et al., 2013 and Khattab et al., 2014). Amino acids are holding as precursors and constituents of proteins which are necessary for promoting cell development. They consisted of both acid and basic groups and act as buffers, which led to remain favorable $\mathrm{pH}$ value inside the plant cell (Davies 1982). Amino acids can directly or indirectly influence physiological activities in plant growth and development. Amino acids are basic ingredients in the procedure of protein synthesis. The requirements of amino acids are of a prime important to enhance yield, quality and overall the plant growth and development. Amino acids application use is essential particularly at the critical stages of growth. The basic role of amino acids was the biosynthesis of organic foods and increment cell division which reflect on enhancing growth and nutritional status (Ahmed and Abd El-Hameed 2003 and Sabry et al. 2009). External implementation of amino acids has been appraised to improve the growth and fruiting of pomegranate trees (Khattab et al., 2014; Wassel et al., 2015; Kamal 2017 and Mohamed et al., 2020). These results were supported by the results of (Aseri et al., 2008); Fayek et al., 2011), Khan et al. (2012); Omima et al., (2014) and Arabloo et al., (2017).

\section{Conclusion}

From the current results of this study, it could be concluded that spraying of either humic acid at $1 \%$ or amino acids at $0.5 \%$ three times during the fruit growth of manfalouty pomegranate. These applications are favorable to obtain high yield and reduction fruit cracking percentage with best fruit quality.

\section{References}

Abd El-Razek, E., Abd-Allah, A.S.E. and Saleh, M.M.S. (2012) 'Yield and Fruit Quality of Florida Prince Peach Trees as affected by Foliar and Soil applications of Humic Acid' Journal of Applied Sciences Research, 8: pp. 5724-5729.

Adam, M.S. (1999) 'Promotive effect of Cyanobacteria Nostoc Muscorum on the growth of some crop plants' Acta Microbiologioolinica, 48 (2): pp. 163-171 
Ahmed, A.M. and Abd El-Hameed, H.M. (2003)

'Growth, uptake of some nutrients and productivity of red roomy vines as affected by spraying of some amino acids, magnesium and boron' Minia J. Agric. Res. And Develop, 23: 649-666.

A.O.A.C, (2000) 'Official Methods of Analysis, 17th ed. As-sociation of Official Analytical Chemists, USA'

Arabloo, M., Taheri, M., Yazdani, H. and Shahmoradi, M. (2017) 'Effect of foliar application of amino acid and calcium chelate on some quality and quantity of Golden Delicious and Granny Smith apples' Trakia J.l Sci., 15 (1):14-19.

Aseri, G.K., Jain, N., Panwar, J., Rao, A.V. and. Meghwal, P.R. (2008) 'Biofertilizers improve plant growth, fruit yield, nutrition, metabolism and rhizosphere enzyme activities of pomegranate (Punica granatum L.) in indian thar desert' Scientia Horticulturae, 117: pp. 130-135.

Aviram, M., Dorenfeld, L., Rosenblat, M.;Volkova, N., Kaplan, M., Hayeck,T., Presser, D.and Fuhrman, B. (2000) 'Pomegranate juice consumption reduces oxidative stress, atherogenic modifications to LDL, and platelet aggregation: studies in humans and in atherosclerotic apolipoprotein E-deficient mice' Am. J. Clin. Nutr. 71, 1062-1076.

Cam, M. and Hisil, Y. (2010) 'Pressurized water extraction of polyphenols from pomegranate peels' Food Chem., 123 (3): 878-885.

Canellas, L.P., Olivares, F.L., Aguiar, N.O., Jones, D.L., Nebbioso, A., Mazzei, P. and Piccolo, A. (2015) 'Humic and fulvic acids as biostimulants in horticulture' Sci Hortic 196:15-27.

Davies, D.D. (1982). 'Physiological aspects of protein turn over' Encycl. Plant Physiol., 45: 481- 487.

Duncan, D.B. (1955) 'Moldable rang and moldable F test' Biometrics 11: 1-24.
El-Mohamedy, R.S.R. and Ahmed, M.A. (2009) 'Effect of bio-fertilizers and humic acid on control of dry root-rot disease and improvement yield and quality of mandarin' Research J. Agric. Biol. Sci. 5 (2): 127-139.

Fayek, M.A., Yehia, T.A. , El-Fakhrany, E.M.M. and Farag, A.M (2011) 'Effect of Ringing and Amino Acids Application on Improving Fruiting of Le Conte Pear Trees' J. Hort. Sci. Ornamental Plants, 3 (1): 0110, 2011.

Ferrara, G. and Brunetti, G. (2010) 'Effects of the times of application of a soilhumic acid on berry quality of table grape (Vitis vinifera L.) cv Italia.Spanish' Journal of Agricultural Research 8 (3): 817-822.

Ghanbarpour E. M. Rezaei1 and Lawson, S. (2018) 'Reduction of Cracking in Pomegranate Fruit After Foliar Application of Humic Acid, Calcium-boron and Kaolin DuringWater Stress. Springer'Verlag GmbH Deutschland, ein Teil von Springer Nature 2018.

Gil, M.I., Tomas-Barberan, F.A, Hess-Pierce, B., Holcroft, D.M. and Kader, A.A. (2000) 'Antioxidant activity of pomegranate juice and its relationship with phenolic composition and processing' J. Agric. Food Chem., 48: 4581-4589.

Hagagg, L.F., Shahin, M.F.M., Merwad, M.A., Fikria, H. and Eman S. El-Hady, (2013) 'Improving fruit quality and quantity of "Aggizi" olive trees byapplication of humic acid during full bloom and fruit set stages' Middle East Journal of Agriculture Research, 2(2): 44-50.

Kamal H. M., Elisa, M. A and Mohammed, A. A (2017) 'Effect of some mineral compounds on yield and fruit quality of pomegranate' Bioscience Research, 2017 14(4): 11971203.

Khan, A.S., Ahmed, B., Jaskani, M.J., Ahmed, R. and Malik, A.U. (2012) 'Foliar application of mixture of amino acids and seaweed (Ascophylum nodosum) extract 
improve growth and physico-chemical properties of grapes' Int. J. Agric. Biol. 14 (3), pp. 385-388.

Khattab, M.M., Shaban, AE., El-Shrief, A.H. and Mohamed, A. (2014) 'Effect of humic acid and amino acid on pomegranate trees under deficit irrigation. II: growth, flowering and fruiting' American-Eurasian J. Agric. \& Environ. Sci., 14 (9): 941-948, 2014, ISSN 1818-6769.

Lanksy,E,P and Newman, R.A. (2007) 'Review punica granatum (pomegranate) and its potential for prevention and treatment of inflammation and cancer' J.Ethnopharm., 109:177-206.

Liu, C., Copper, R.J. and Bowman, D.C. (1998) 'Humic acid application effects photosynthesis root development and nutrient content of creeping bent grass' Hort. Sci. 33: 1023-1025.

Lotfi, R., Gharavi-Kouchebagh, P. and Khoshvaghti, H. (2015) 'Biochemical and physiological responses of Brassicanapus plants to humic acid under water stress'. Russ J Plant Physiol 62:480-486. https:// doi.org/10.1134/S1021443715040123.

Mehran, M., Samavat, S., Mostafavi, M., Khalighi, A. and Cherati, A. (2013) 'The Effects of Proline and Humic acid on Quantitative Properties of Kiwifruit' International Research Journal of Applied and Basic Sciences, 6(8): 117-119.

Moghadam Tohidi, H.R. (2015) 'Humic acid as an ecological pathway to protect corn plants against oxidative stress' Biol Forum 7(1):1704-1709.

Mohamed, A.K.A., Abdel-Galil, H. A. and Naglaa H. Galal, (2020) 'Effect of some nutrients and amino acids spraying on yield and fruit quality of Manfalouty pomegranate'

10.21608/svuijas.2020.32877.1014

Muscolo, A., Sidari, M. and Attina, E. (2007) 'Biological activity of humic substances is related to their chemical structure' Soil Sci. Soc. Amer. J. 71: 75-85.

Omima M. El Sayed., Elgammal, O.H.M. and Salama, A.S.M. (2014) 'Effect of proline and tryptophan amino acids on yield and fruit quality of Manfalouty pomegranate variety. Scintia' Hort., 169: 1-5.

Rabino, I. and Mancinelli, A.L. (1986) 'Light, temperature and anthocyanin production' $J$. Plant Physiol., 81 (3): 922-924.

Sabry, G.H., Mervat Rizk, S. and Abd ElWahab, M.A. (2009) 'Influence of effective micro-organisms, seaweed extract and amino acids application on growth, yield and bunch quality of Red Globe grapevines' J. Agric. Sci. Mansoura Univ., 34: 5901-5921.

Sarkhosh, A., Zamani, Z., Fatahi, R. and Ebadi, A. (2006) 'RAPD markers reveal polymorphism among some Iranian pomegranate (Punica granatum L.) genotypes' Sci. Hort., 111: 24-29.

Shukla, M.; Gupta, K.; Rasheed, Z.; Khan, K.A. and Haqqi, T.M. (2008) 'Bioavailable constituents/ metabolites of pomegranate (Punica granatum L.) preferentially inhibit COX2 activity ex vivo and IL- 1betainduced PGE2 production in human chondrocytes in vitro' J. Inflammation, 5: 1 9.

Snedecor, G.W. and Cochran, W.G. (1972) 'Statistical Methods, 6th Ed. The Iowa State University Press, Ames, Iowa, U.S.A'

Tung, Y.H.O.; Quigg, A. ; Finkel, Z.V. ; Milligan, A.J. Wyman, ; K. ; Falkowski, P.G. and Morel, F.M.M. (2003) 'The elemental composition of some marine phytoplankton'. J. of Phycology, 39 (1): 1020.

Wassel, A.H.M.; Gobara A.A.; Ibrahiem, H.I.M. and Shaaban, M.M, (2015) 'Response of Wonderful Pomegranate trees to foliar application of Amino Acids, Vitamins B and Silicon' World Rural Observations, 7(3), pp. 91-95. 